\title{
Development and Validation of a New Spectrophotometric Method for the Determination of Cephalexin Monohydrate in Pure Form and Pharmaceutical Formulations
}

\author{
Muhammad N. Khan,* Jalal Ahmad, Muhammad N. Jan, Hussain Gulab and \\ Muhammad Idrees
}

Department of Chemistry, Bacha Khan University, 24420 Charsadda-KPK, Pakistan

\begin{abstract}
A simple, fast, sensitive and accurate spectrophotometric method has been developed for the quantitative determination of cephalexin monohydrate in dosage form and in commercial formulations. The method involves the addition of $\mathrm{Ce}^{\mathrm{IV}}$ to cephalexin in acidic medium, followed by the determination of residual $\mathrm{Ce}^{\mathrm{IV}}$ by reacting with a fixed amount of methyl orange, and the absorbance was measured at $510 \mathrm{~nm}$. Beer's law was obeyed in the concentration range of 0.6-20 $\mu \mathrm{g} \mathrm{mL}^{-1}$ with correlation coefficient of 0.992 . The molar absorptivity was calculated and was found to be $9.8 \times 10^{4} \mathrm{~L} \mathrm{~mol}^{-1} \mathrm{~cm}^{-1}$. Different variables affecting the reaction conditions such as concentration and volume of $\mathrm{Ce}^{\mathrm{IV}}$, type and concentration of acids used, reaction time and temperature were carefully studied and optimized. The limit of detection (LOD) and limit of quantification (LOQ) were calculated and found to be 0.221 and $0.736 \mu \mathrm{g} \mathrm{mL}^{-1}$, respectively. The proposed method was found to have good reproducibility with a relative standard deviation of $4.4 \%(\mathrm{n}=9)$. The interference effects of common excipients found in pharmaceutical preparations were studied. The developed method was validated statistically by performing recoveries studies and successfully applied for the determination of cephalexin in bulk powder and pharmaceutical preparations. Percent recoveries were calculated and found to range from 90.6 to $102.9 \%$ for bulk powder and from 98.7 to $104.8 \%$ for pharmaceutical preparations.
\end{abstract}

Keywords: cephalexin monohydrate, cerium(IV), methyl orange, redox reaction

\section{Introduction}

Cephalexin (CPX), (7R)-7-(D- $\alpha$-amino- $\alpha-$ phenylacetamido)-3-methyl-3-cephem-4-carboxylic acid hydrate or $(6 R, 7 R)-7-\{[(2 R)-2$-amino-2-phenylacetyl $]$ amino -3-methyl-8-oxo-5-thia-1-azabicyclo[4.2.0] oct-2-ene-2 carboxylic acid hydrate (Figure 1) is a first generation $^{1}$ semi-synthetic derivative of cephalosporin, which is a powerful tool against gram-positive and gramnegative bacteria.

It exhibits a broad spectrum of activities, which have the ability to weakly bond with blood protein, therefore, have no metabolites, low toxicity and rapid absorptivity. ${ }^{2}$ It is a hydrosoluble, amphoteric compound, having isoelectric point of $4.3 .^{3}$ The drug is, therefore, widely used for the clinical chemotherapy like middle ear infections, strep throat, bone and joint infections, pneumonia, skin infections, and urinary tract infections. It may be used to prevent

*e-mail: mnaeemchemist@yahoo.com<smiles>CC1=C(C(=O)O)N2C(=O)C(NC(=O)[C@@H](N)c3ccccc3)C2SC1</smiles>

Figure 1. Chemical structure of cephalexin monohydrate.

bacterial endocarditis, and is taken orally. It is not effective against methicillin-resistant Staphylococcus aureus. It may be used in those who have mild or moderate allergies to penicillin but is not recommended to those having severe allergies. It has no effect against viral infections. ${ }^{4}$ Actually cephalosporins operate by inhibiting bacterial cell wall biosynthesis. $^{5}$

In the literature a large number of analytical methods have been proposed for the determination of cephalexin in pure form, in pharmaceutical preparations, and in biological fluids. But the problems with these methods are: they 
are expensive, time consuming and have environmental effect, mostly temperature dependence. These methods include chromatographic, ${ }^{6-9}$ spectrofluorimetric, ${ }^{10-12}$ atomic absorption, ${ }^{13,14}$ capillary electrophoresis ${ }^{15}$ and flow injection analysis. ${ }^{16,17}$ However few spectrophotometric methods have been reported in the literature ${ }^{18-22}$ for the determination of cephalexin and most reported methods involve multistep procedures, and have poor selectivity and sensitivities and narrow linear ranges. Spectrophotometry is considered as one of the most suitable analytical techniques for the analysis of pharmaceutical compounds, because of its low cost, simplicity, wide linear dynamic range and wide availability.

The present study is an effort of developing a simple, fast, inexpensive, accurate, sensitive and free of pronounced environmental effects method, which enable the determination of species of interest with a higher sensitivity and greater reproducibility. The method involves the addition of $\mathrm{Ce}^{\mathrm{IV}}$ to cephalexin in acidic medium, followed by the determination of residual $\mathrm{Ce}^{\mathrm{IV}}$ by reacting with a fixed amount of methyl orange and the absorbance was measured at $510 \mathrm{~nm}$. The amount of $\mathrm{Ce}^{\mathrm{IV}}$ reacted corresponds to the amount of cephalexin and measured absorbance was found to increase linearly with the concentration of cephalexin.

\section{Experimental}

\section{Materials and reagents}

All reagents used were of analytical or of high grade purity and used without further purification. Distilled water was used throughout the work. Cerium sulfate tetrahydrate $\left(\mathrm{Ce}\left(\mathrm{SO}_{4}\right)_{2} \cdot 4 \mathrm{H}_{2} \mathrm{O}\right)$ (Riedel-deHaën), nitric acid $65 \%$ (Sigma-Aldrich) and methyl orange (Fisher Chemical UK Limited), were used in this work. Standard reference cephalexin was gifted by pharmaceutical company. Commercial formulations of cephalexin Ceporex capsules $250 \mathrm{mg}$ (manufactured by Glaxo SmithKlin, GSK, Pharmaceuticals Pakistan Limited Korangi Industrial area Karachi), and Nenflex capsules 500 mg (manufactured by Nenza Pharmaceuticals Industries, Pvt, Ltd, Industrial State Hayatabad Peshawar Pakistan) were purchased locally.

\section{Instruments}

A double-beam UV-1800, ENG 240V spectrophotometer Shimadzu with $1 \mathrm{~cm}$ matched quartz cells was used to measure absorbance. A digital analytical balance (OHAUS Corporation USA) and digital water bath, Labacon, model LWB-104, single hexode was also used.

\section{Preparation of reagents solutions}

Nitric acid $\left(1.0 \mathrm{~mol} \mathrm{~L}^{-1}\right)$ solution was prepared fresh daily by dissolving $3.21 \mathrm{~mL}$ of $\mathrm{HNO}_{3}$ in distilled water and diluted to $50 \mathrm{~mL}$ with distilled water. $\mathrm{Ce}^{\mathrm{IV}}\left(2 \times 10^{-3} \mathrm{~mol} \mathrm{~L}^{-1}\right)$ solution was prepared by dissolving $0.0404 \mathrm{~g}$ of $\mathrm{Ce}\left(\mathrm{SO}_{4}\right)_{2} \cdot 4 \mathrm{H}_{2} \mathrm{O}$ in $5 \mathrm{~mL} \mathrm{H}_{2} \mathrm{SO}_{4}\left(1.00 \mathrm{~mol} \mathrm{~L}^{-1}\right)$ and diluted to $50 \mathrm{~mL}$ with distilled water. Methyl orange $\left(1 \times 10^{-3} \mathrm{~mol} \mathrm{~L}^{-1}\right)$ solution was prepared by dissolving $0.0163 \mathrm{~g}$ of the reagent in distilled water and diluted up to $50 \mathrm{~mL}$ with distilled water. Working solutions of the required concentration $\left(6 \times 10^{-4} \mathrm{~mol} \mathrm{~L}^{-1}\right)$ was prepared fresh daily by diluting appropriate volume of the stock solution with distilled water.

\section{Preparation of standard solution}

A standard stock solution of cephalexin $\left(100 \mu \mathrm{g} \mathrm{mL}^{-1}\right)$ was prepared by dissolving $0.01 \mathrm{~g}$ of standard cephalexin in distilled water with heating $\left(70^{\circ} \mathrm{C}\right)$ and diluted to $100 \mathrm{~mL}$ with the same solvent. Working solutions of required concentrations were prepared fresh daily before use from stock solution by dilution with distilled water.

Recommended procedures for preparation of analytical curve

An appropriate volume of cephalexin stock solution diluted to give final concentration of $0.6-20 \mu \mathrm{g} \mathrm{mL}^{-1}$ was added in a set of reaction flasks. $2.0 \mathrm{~mL}$ of $1.0 \mathrm{~mol} \mathrm{~L}^{-1}$ nitric acid was added followed by $1.5 \mathrm{~mL}$ of $2 \times 10^{-3} \mathrm{~mol} \mathrm{~L}^{-1} \mathrm{Ce}^{\mathrm{IV}}$. The contents of the flasks were set aside for 15 minutes with occasional shaking. Finally, $1.5 \mathrm{~mL}$ of $6 \times 10^{-4} \mathrm{~mol} \mathrm{~L}^{-1}$ methyl orange solution was added to each flask. The solutions were transferred to $10 \mathrm{~mL}$ volumetric flasks and the volume was adjusted up to the mark with distilled water. The absorbance of each solution was measured at $510 \mathrm{~nm}$ against the corresponding reagent blank.

\section{Application to pharmaceutical preparations}

The contents of three tablets of each sample, i.e., Ceporex (250 mg per capsule) and Nenflex (500 mg per capsule) were weighed separately to get the average weight of one capsule. Powder equivalent to $0.01 \mathrm{~g}\left(100 \mu \mathrm{g} \mathrm{mL}^{-1}\right)$ of cephalexin were then dissolved in distilled water with heating $\left(70^{\circ} \mathrm{C}\right)$. The resultant solutions were then filtered and diluted to $100 \mathrm{~mL}$ with distilled water. An appropriate volume of this solution was then diluted with distilled water to obtain a cephalexin concentration within the working range. Aliquots of these solutions were then analyzed using the procedure described for the preparation of analytical 
curve and actual cephalexin contents in samples were calculated using the calibration equation.

\section{Results and Discussion}

$\mathrm{Ce}^{\mathrm{IV}}$ has been used as an oxidizing agent in the determination of many pharmaceutical compounds by spectrophotometric ${ }^{23,24}$ and spectrofluorimetric ${ }^{25-27}$ methods or by both of them ${ }^{28,29}$ and chemiluminescence. ${ }^{30}$ The proposed method involves the addition of $\mathrm{Ce}^{\mathrm{IV}}$ to cephalexin in acidic medium, followed by the determination of residual $\mathrm{Ce}^{\mathrm{IV}}$ by reacting with a fixed amount of methyl orange, and the absorbance was measured at $510 \mathrm{~nm}$ (Figure 2).

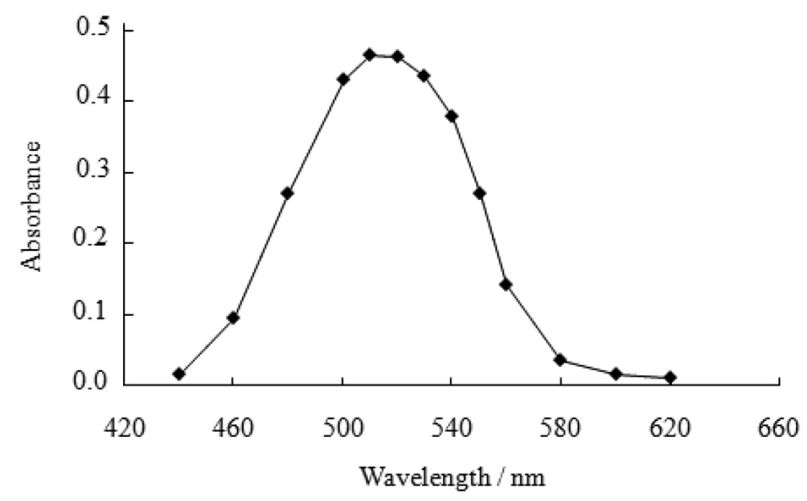

Figure 2. Absorption spectrum of cephalexin. Conditions: $20 \mu \mathrm{g} \mathrm{mL} \mathrm{m}^{-1}$ cephalexin, $2 \mathrm{~mL}$ of nitric acid $\left(1 \mathrm{~mol} \mathrm{~L}^{-1}\right), 1 \mathrm{~mL}^{\circ} \mathrm{Ce}^{\mathrm{IV}}\left(5 \times 10^{-3} \mathrm{~mol} \mathrm{~L}^{-1}\right)$, $1.5 \mathrm{~mL}$ of methyl orange $\left(5 \times 10^{-4} \mathrm{~mol} \mathrm{\textrm {L } ^ { - 1 }}\right)$, diluted to $10 \mathrm{~mL}$, $\lambda$ 440-620 nm.

\section{Optimization of reaction conditions}

A series of experiments was conducted to establish the optimum experimental variables at which maximum and reproducible analytical results were achieved. The parameters optimized included the effect of acidity, $\mathrm{Ce}^{\mathrm{IV}}$, dye and time.

\section{Effect of $\mathrm{Ce}^{\mathrm{IV}}$ concentration}

The influence of $\mathrm{Ce}^{\mathrm{IV}}$ on the color intensity of the reaction was studied. To find the optimum concentration of $\mathrm{Ce}^{\mathrm{IV}}$, the effect of $\mathrm{Ce}^{\mathrm{IV}}$ concentration was investigated in the range of $1 \times 10^{-4}-4 \times 10^{-3} \mathrm{~mol} \mathrm{~L}^{-1}$. Maximum and constant absorbance of color product was obtained with $2 \times 10^{-3} \mathrm{~mol} \mathrm{~L}^{-1} \mathrm{Ce}^{\mathrm{IV}}$ solution (Figure 3). The volume of $\mathrm{Ce}^{\mathrm{IV}}$ solution was also optimized and $1.5 \mathrm{~mL}$ of $2 \times 10^{-3} \mathrm{~mol} \mathrm{~L}^{-1}$ $\mathrm{Ce}^{\mathrm{IV}}$ solution produced maximum colored formation.

\section{Effect of acid type and concentration}

The oxidation reaction was carried out in acidic medium to avoid the precipitation of hydrated ceric oxide $\mathrm{CeO}_{2} \cdot \mathrm{H}_{2} \mathrm{O}$. Different acids such as $\mathrm{H}_{2} \mathrm{SO}_{4}, \mathrm{HCl}$ and $\mathrm{HNO}_{3}$ were tried

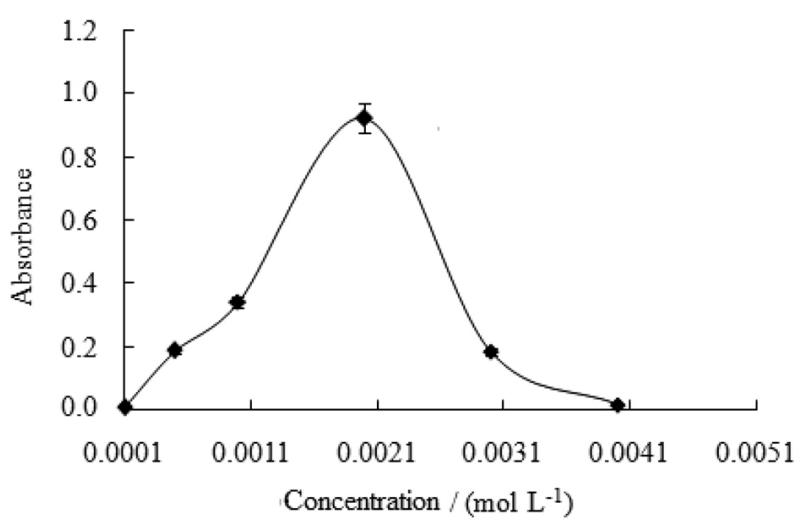

Figure 3. Effect of $\mathrm{Ce}^{\mathrm{IV}}$ concentration. Conditions: $20 \mu \mathrm{g} \mathrm{mL} \mathrm{m}^{-1}$ cephalexin, $2 \mathrm{~mL}$ of nitric acid $\left(1 \mathrm{~mol} \mathrm{~L}^{-1}\right), 1 \mathrm{~mL}$ of Ce $\mathrm{Ce}^{\mathrm{IV}}\left(1 \times 10^{-4}-4 \times 10^{-3} \mathrm{~mol} \mathrm{~L}^{-1}\right)$, $1.5 \mathrm{~mL}$ of methyl orange $\left(5 \times 10^{-4} \mathrm{~mol} \mathrm{~L}^{-1}\right)$, diluted to $10 \mathrm{~mL}, \lambda_{\max } 510 \mathrm{~nm}$.

to determine the most suitable acid for optimum reaction development. Maximum absorbance was obtained by using $1.0 \mathrm{~mol} \mathrm{~L}^{-1} \mathrm{HNO}_{3}$ (Figure 4).

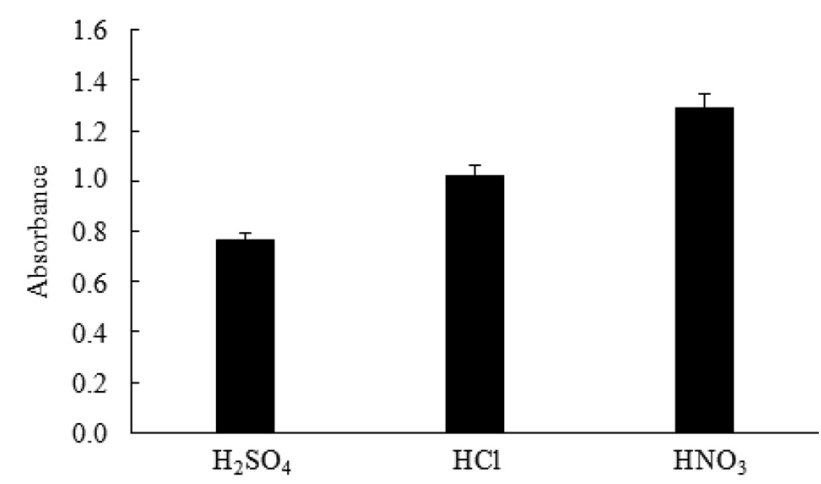

Figure 4. Effect of acid type and concentration. Conditions: $20 \mu \mathrm{g} \mathrm{mL}^{-1}$ cephalexin, $2 \mathrm{~mL}$ of $\mathrm{H}_{2} \mathrm{SO}_{4}, \mathrm{HCl}$ and $\mathrm{HNO}_{3}(1 \mathrm{~mol} \mathrm{~L}-1), 1 \mathrm{~mL}$ of $\mathrm{Ce}^{\mathrm{IV}}$ $\left(2 \times 10^{-3} \mathrm{~mol} \mathrm{~L}^{-1}\right), 1.5 \mathrm{~mL}$ of methyl orange $\left(5 \times 10^{-4} \mathrm{~mol} \mathrm{~L}^{-1}\right)$, diluted to $10 \mathrm{~mL}, \lambda_{\max } 510 \mathrm{~nm}$.

\section{Effect of dye concentration}

The effect of dye concentration on the intensity of color developed was tested using different concentration of dye. To find the optimum concentration of methyl orange, the effect of methyl orange concentration was studied in the range 3-8 $\times 10^{-4} \mathrm{~mol} \mathrm{~L}^{-1}$. Maximum colored formation was observed with $6 \times 10^{-4} \mathrm{~mol} \mathrm{~L}^{-1}$ of methyl orange (Figure 5). The effect of volume of methyl orange solution was also investigated and $1.5 \mathrm{~mL}$ of $6 \times 10^{-4} \mathrm{~mol} \mathrm{~L}^{-1}$ of methyl orange solution give maximum absorbance.

\section{Effect of time and temperature}

The reaction between cephalexin and $\mathrm{Ce}^{\mathrm{IV}}$ in the presence of $\mathrm{HNO}_{3}$ was completed after 10 min of mixing, but 15 min was sufficient to get maximum absorbance. The absorbance for minimum and maximum times is 0.537 and 0.753 , respectively. The effect of temperature was 


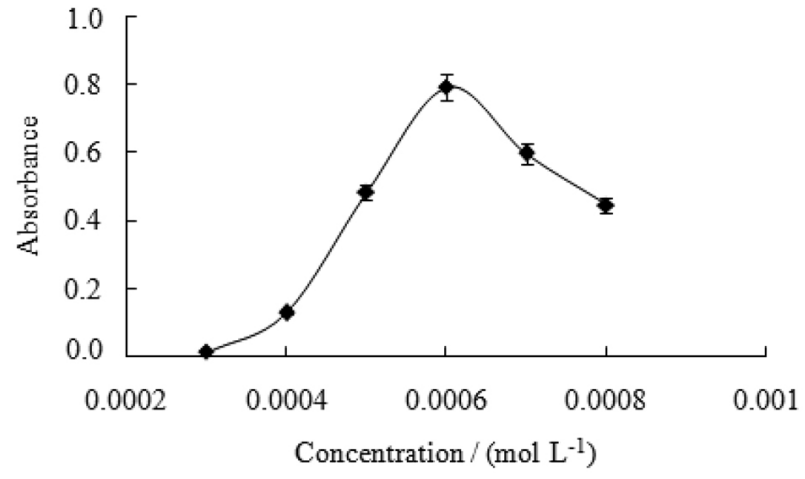

Figure 5. Effect of methyl orange concentration. Conditions: $20 \mu \mathrm{g} \mathrm{mL}^{-1}$ cephalexin, $2 \mathrm{~mL}$ of $\mathrm{HNO}_{3}\left(1 \mathrm{~mol} \mathrm{~L}^{-1}\right), 1 \mathrm{~mL}$ of $\mathrm{Ce}^{\mathrm{IV}}\left(2 \times 10^{-3} \mathrm{~mol} \mathrm{~L}^{-1}\right)$, $1.5 \mathrm{~mL}$ of methyl orange $\left(3-8 \times 10^{-4} \mathrm{~mol} \mathrm{~L}^{-1}\right)$, diluted to $10 \mathrm{~mL}$, $\lambda_{\max } 510 \mathrm{~nm}$.

studied in the range of $25-70{ }^{\circ} \mathrm{C}$. Raising the temperature does not accelerate the oxidation process and does not give reproducible results, so the reaction was carried out at room temperature. The color produced from the reaction between the remaining unreacted $\mathrm{Ce}^{\mathrm{IV}}$ and methyl orange develops immediately.

\section{Stability of the complex}

The stability of the complex was investigated by measuring absorbance regularly for up to 60 minutes. It was observed that no change in absorbance occurred. Thus the complex formed is stable and will not affect the results of analysis even if the absorbance is measured after 1 hour of dilution (Figure 6).

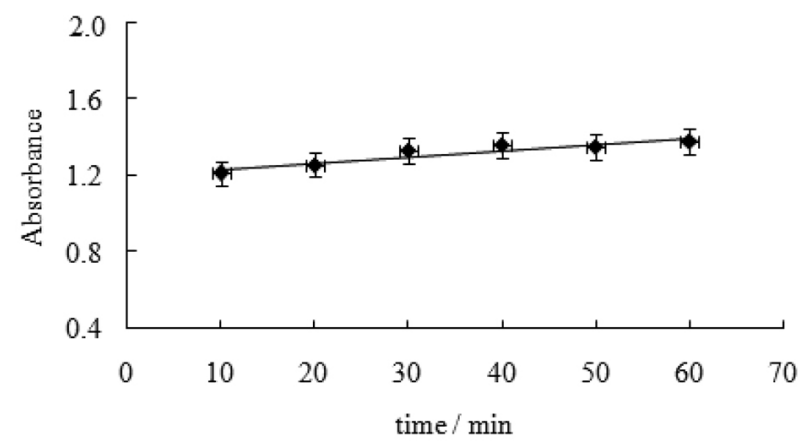

Figure 6. Effect of time on stability of reaction product after dilution. Conditions: $20 \mu \mathrm{g} \mathrm{mL}^{-1}$ cephalexin, $2 \mathrm{~mL}$ of $\mathrm{HNO}_{3}\left(1 \mathrm{~mol} \mathrm{~L}^{-1}\right), 1 \mathrm{~mL}$ of $\mathrm{Ce}^{\mathrm{IV}}\left(2 \times 10^{-3} \mathrm{~mol} \mathrm{~L}^{-1}\right), 1.5 \mathrm{~mL}$ of methyl orange $\left(6 \times 10^{-4} \mathrm{~mol} \mathrm{~L}^{-1}\right)$, diluted to $10 \mathrm{~mL}, \lambda_{\max } 510 \mathrm{~nm}$.

\section{Analytical figures of merit}

Under the optimum experimental conditions of the proposed method, a linear correlation was found between absorbance and cephalexin concentration. Beer's law was obeyed in the concentration range of $0.6-20 \mu \mathrm{g} \mathrm{mL}^{-1}$ with a strong correlation coefficient of 0.992 (Figure 7). The limit of detection (LOD) was calculated by using the minimum level of concentration at which cephalexin can be detected reliably $(3.3 \times$ standard deviation, SD) using nine replicates determination and was found to be $0.221 \mu \mathrm{g} \mathrm{mL}^{-1}$. The limit of quantification (LOQ) was similarly calculated by using the lowest concentration of cephalexin that can be measured with satisfactory precision and accuracy $(10 \times \mathrm{SD})$ and was found to be $0.736 \mu \mathrm{g} \mathrm{mL}$. The optical characteristic such as the linear regression equation, intercept, slope, correlation coefficient, and relative standard deviation of the response factor are given in Table 1 . The molar absorptivity was calculated and was found to be $9.8 \times 10^{4} \mathrm{~L} \mathrm{~mol}^{-1} \mathrm{~cm}^{-1}$. The sensitivity of the proposed method is compared with other reported methods in Table 2, which shows that sensitivity of the present method is greater than those of previously reported methods. Only the spectroflurometric method has greater sensitivity than the present method due to its lower limit of detection but it has a narrow range as compared to the present method.

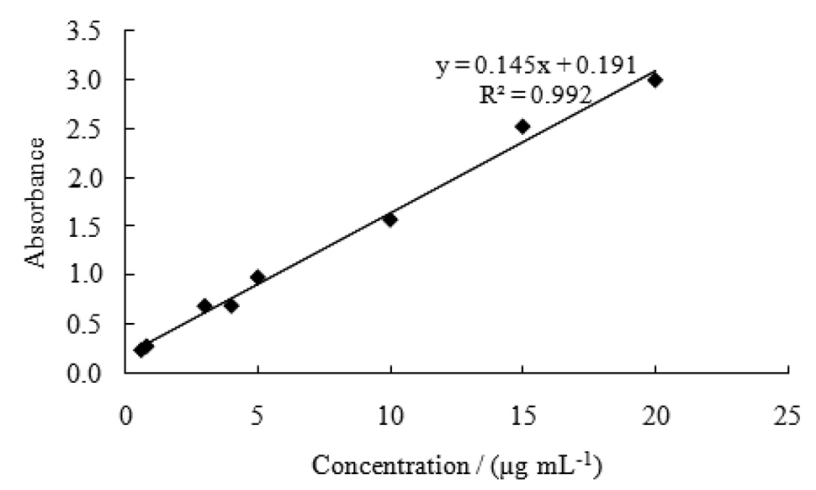

Figure 7. Effect of concentration of cephalexin on absorbance. Conditions: 0.6-20 $\mu \mathrm{g} \mathrm{mL}-1$ cephalexin, $2 \mathrm{~mL}$ of $\mathrm{HNO}_{3}\left(1 \mathrm{~mol} \mathrm{~L}^{-1}\right), 1 \mathrm{~mL}$ of $\mathrm{Ce}^{\mathrm{IV}}$ $\left(2 \times 10^{-3} \mathrm{~mol} \mathrm{~L}^{-1}\right), 1.5 \mathrm{~mL}$ of methyl orange $\left(6 \times 10^{-4} \mathrm{~mol} \mathrm{~L}^{-1}\right)$, diluted to $10 \mathrm{~mL}, \lambda_{\max } 510 \mathrm{~nm}$.

Table 1. Optical characteristics and statistical analysis of calibration graphs for the determination of cephalexin by the proposed method

\begin{tabular}{lc}
\hline Parameter & Value \\
\hline Wavelength $\left(\lambda_{\max }\right) / \mathrm{nm}$ & 510 \\
Linear range $/(\mu \mathrm{g} \mathrm{mL}-1)$ & $0.6-20$ \\
Molar absorptivity / $\left(\mathrm{L} \mathrm{mol}^{-1} \mathrm{~cm}^{-1}\right)$ & $9.8 \times 10^{4}$ \\
Limit of detection / $\left.(\mu \mathrm{g} \mathrm{mL})^{-1}\right)$ & 0.221 \\
Limit of quantification / $(\mu \mathrm{g} \mathrm{mL}-1)$ & 0.736 \\
Regression equation & $\mathrm{y}=0.145 \mathrm{x}-0.191$ \\
Slope $(\mathrm{b})$ & 0.145 \\
Intercept $(\mathrm{a})$ & -0.191 \\
Determination coefficient $\left(\mathrm{R}^{2}\right)$ & 0.992 \\
Standard deviation / $\left(\mu \mathrm{g} \mathrm{mL} \mathrm{m}^{-1}\right)$ & 0.026 \\
Relative standard deviation / \% & 4.4 \\
\hline
\end{tabular}


Table 2. Comparison of the present method and other reported methods for the determination of cephalexin levels

\begin{tabular}{lccc}
\hline Method & Linear range $/\left(\mu \mathrm{gL}^{-1}\right)$ & Limit of detection $(\mathrm{LOD}) /\left(\mu \mathrm{g} \mathrm{mL} \mathrm{L}^{-1}\right)$ & Reference \\
\hline Spectrophotometry & $1.5-10$ & 0.90 & 2 \\
Spectrofluorimety & $0.04-0.4$ & $7.76^{\mathrm{a}}$ & 10 \\
Atomic absorption spectroscopy & $5-50$ & 1.66 & 14 \\
Spectrophotometry & $5-60$ & 1.22 & 18 \\
HPLC $^{\mathrm{b}}$ & $10-110,10-120$ & $2.236,2.090$ & 31 \\
Spectrophotometry & $0.6-20$ & 0.221 & present method \\
\hline
\end{tabular}

anit: $n g \mathrm{~mL}^{-1}$; ${ }^{\mathrm{b}} \mathrm{HPLC}$ : high-performance liquid chromatography.

\section{Effect of interferences}

The effects of interferences from the commonly used excipients such as sucrose, starch, glucose and fructose used in pharmaceutical preparations of cephalexin were investigated (Figure 8). Under the optimized experimental conditions, to a known amount of drug (cephalexin $0.6 \mu \mathrm{g} \mathrm{mL}{ }^{-1}$ ), excipients in different concentration in the ratio of 1:1, 1:2, 1:4, 1:6, 1:8 and 1:10 were added and investigated by the proposed method. A 5\% error criterion was adopted. None of these common excipients was found to cause interferences at lower concentrations. But at higher concentration the sucrose and fructose was found to produce non-significant interferences.

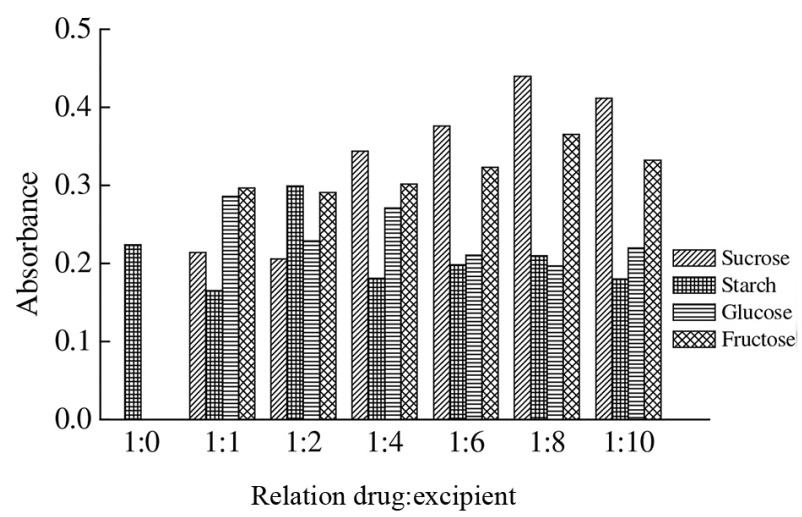

Figure 8. Effect of common excipients on determination of cephalexin by the proposed method.

\section{Reliability of the method}

The precision of the developed method was investigated by determining cephalexin in pure form and pharmaceuticals preparations using three different concentrations within the calibration curve range, in triplicate. Results are listed in Table 3 for the standard and in Table 4 for pharmaceutical preparations. The percent recoveries obtained ranged from 90.6 to $102.9 \%$ for the standard and 98.7 to $104.8 \%$ for pharmaceutical preparations with narrow relative
Table 3. Accuracy and precision of the present method using standard cephalexin solution

\begin{tabular}{lcc}
\hline $\begin{array}{l}\text { Amount taken } \\
\left.(\mu \mathrm{g} \mathrm{mL})^{-1}\right)\end{array}$ & $\begin{array}{c}\text { Amount found } \\
\left(\mu \mathrm{g} \mathrm{mL}^{-1}\right)\end{array}$ & Recovery $\pm \mathrm{RSD}^{\mathrm{b}} / \%$ \\
\hline 0.6 & 0.544 & $90.6 \pm 1.1$ \\
0.8 & 0.812 & $101.6 \pm 1.4$ \\
1.0 & 1.029 & $102.9 \pm 3.6$ \\
\hline Mean & \multicolumn{3}{c}{98.4} \\
Standard deviation & \multicolumn{3}{c}{ \pm 6.7} \\
$t$-test & \multicolumn{2}{c}{$0.42(4.303)$} \\
\hline
\end{tabular}

a Results are the averages of three separate analyses; ${ }^{\text {RSSD: relative }}$ standard deviation.

Table 4. Evaluation of accuracy and precision of the present method for cephalexin determination in pharmaceutical preparations

\begin{tabular}{lccc}
\hline $\begin{array}{l}\text { Pharmaceutical } \\
\text { preparation }\end{array}$ & $\begin{array}{c}\text { Amount taken } \\
\left(\mu \mathrm{g} \mathrm{mL}^{-1}\right)\end{array}$ & $\begin{array}{c}\text { Amount found } \\
\left(\mu \mathrm{g} \mathrm{mL}^{-1}\right)\end{array}$ & $\begin{array}{c}\text { Recovery } \pm \\
\mathrm{RSD}^{\mathrm{b}} / \%\end{array}$ \\
\hline Ciporex capsule & 0.6 & 0.592 & $98.7 \pm 7.2$ \\
$(250 \mathrm{mg})$ & 0.8 & 0.791 & $98.9 \pm 5.9$ \\
\hline Nenflex capsule & 1.0 & 1.026 & $102.6 \pm 3.1$ \\
\hline $500 \mathrm{mg})$ & 0.6 & 0.629 & $104.8 \pm 2.2$ \\
& 0.8 & 0.830 & $103.7 \pm 5.2$ \\
\hline
\end{tabular}

${ }^{a}$ Results are the averages of three separate analyses; ${ }^{b} \mathrm{RSD}$ : relative standard deviation.

standard deviations, indicating that proposed method has good reproducibility. The accuracy of the present method was investigated by standard addition method using two different brands of drugs Ciporex capsule $(250 \mathrm{mg}$ ) and Nenflex capsule $(500 \mathrm{mg})$. Certain amounts of standard cephalexin solution were added to tablet solutions and analyzed by the proposed method. Recoveries were calculated by comparing the results obtained before and after adding standard cephalexin solution, and percent recoveries ranged from 95.7 to $103.2 \%$ (Table 5).

\section{Applicability of the proposed method}

The devised method was successfully applied to the determination of cephalexin in the two pharmaceutical 
Table 5. Evaluation of cephalexin recovery percent in commercial formulations (capsules) using the standard addition method

\begin{tabular}{lccc}
\hline $\begin{array}{l}\text { Pharmaceutical } \\
\text { preparation }\end{array}$ & $\begin{array}{c}\text { Amount taken } / \\
\left(\mu \mathrm{g} \mathrm{mL}^{-1}\right)\end{array}$ & $\begin{array}{c}\text { Amount found } \\
\left(\mu \mathrm{gL}^{-1}\right)\end{array}$ & $\begin{array}{c}\text { Recovery } \pm \\
\mathrm{RSD}^{\mathrm{b}} / \%\end{array}$ \\
\hline Ciporex capsule & 0.6 & 0.590 & $98.4 \pm 2.4$ \\
$(250 \mathrm{mg})$ & 0.8 & 0.779 & $97.4 \pm 3.6$ \\
& 1.0 & 0.977 & $97.7 \pm 2.9$ \\
\hline Nenflex capsule & 0.6 & 0.581 & $96.8 \pm 2.9$ \\
$(500 \mathrm{mg})$ & 0.8 & 0.826 & $103.2 \pm 1.5$ \\
& 1.0 & 0.957 & $95.7 \pm 1.5$ \\
\hline
\end{tabular}

${ }^{a}$ Results are the averages of three separate analyses; ${ }^{\mathrm{b} R S D}$ : relative standard deviation.

preparations: Ciporex capsule $(250 \mathrm{mg})$ and Nenflex capsule $(500 \mathrm{mg})$. The results obtained were in close agreement with the label quantities (Table 6), which shows that the proposed method can be used to determine cephalexin quantities in pharmaceutical formulations.

Table 6. Determination of cephalexin in pharmaceutical preparations (capsules)

\begin{tabular}{lccc}
\hline Brand name & $\begin{array}{c}\text { Label value / } \\
(\mathrm{mg} \text { per } \text { capsule })\end{array}$ & $\begin{array}{c}\text { Found } \\
\text { value } \pm \mathrm{SD}^{\mathrm{b}}\end{array}$ & $\begin{array}{c}\text { Recovery } \pm \\
\mathrm{RSD}^{\mathrm{c}} / \%\end{array}$ \\
\hline Ciporex capsule & 250 & $250.9 \pm 0.9$ & $100.4 \pm 2.2$ \\
Nenflex capsule & 500 & $522.3 \pm 0.2$ & $104.5 \pm 0.6$ \\
\hline
\end{tabular}

${ }^{a}$ Results are the averages of three separate analyses; ${ }^{b} S D$ : standard deviation; ${ }^{\circ} \mathrm{RSD}$ : relative standard deviation.

\section{Conclusions}

A fast, simple, sensitive, selective and inexpensive spectrophotometric method was developed for quantification of cephalexin that is widely available in the market and manufactured by the indigenous units. The developed method was found to have a wider linear range and lower limits of detection and quantification than other reported methods. The method is rapid and less tedious than many reported spectrophotometric methods. The present method can be applied at ambient temperature; color development is instantaneous and does not require strict $\mathrm{pH}$ control or tedious liquid-liquid extraction step. The change in the acid was proven to be responsible for twice improvement in sensitivity. The method employs inexpensive and easily available chemicals and instrument. The color formed is highly stable leading to very precise results. These advantages make the method a valuable alternative to many existing methods for the determination of cephalexin levels in commercial tablet formulations with good recovery and excellent reproducibility. Finally, excipients commonly found in pharmaceutical preparations did not interfere with the analysis.

\section{Acknowledgments}

The authors are grateful to the Bacha Khan University Charsadda KPK, Pakistan for providing facility to conduct this research.

\section{References}

1. Panda, S. S.; Kumar, R. V. V. B.; Dash, R.; Mohanta, G.; Sci. Pharm. 2013, 81, 1029.

2. Hassan, O. R.; Chem. Sci. Trans. 2013, 2, 1110.

3. Li, F. Y.; Han, J.; Wang, Y.; Ma, J. J.; Yan, S. Y.; J. Chem. 2013, 1.

4. Alhamd, J. K. A.; World J. Pharm. Pharm. Sci. 2014, 3, 1185.

5. El-Shaboury, S. R.; Mohammed, F. A.; Saleh, G. A.; Rageh, A. H.; Nat. Sci. 2010, 2, 432.

6. Hu, Q. L.; Yin, L. C.; Du, H. Y.; Zeng, P. Z.; J. Anal. Methods Chem. 2012, 1.

7. Carroll, M. A.; White, E. R.; Jancsik, Z.; Zarembo, J. E.; J. Antibiot. 1977, 30, 397.

8. Hsu, M. C.; Lin, Y. S.; Chung, H. C.; J. Chromatogr. A 1995, $692,67$.

9. Jeswani, R. M.; Sinha, P. K.; Topagi, K. S.; Damle, M. C.; Int. J. Pharm. Tech. Res. 2009, 1, 527.

10. El-Wasseef, R. D.; Spectrosc. Lett. 2007, 40, 797.

11. Dani, M. A. M. R.; Elbashir, A. A.; Int. J. Pharm. Chem. Res. 2013, 2,1 .

12. Zhang, J.; Wang, Z.; Mi, T.; Wenren, L.; Wen, K.; Food Anal. Methods 2014, 7, 879.

13. Al-Noor, H. T.; Jarad, J. A.; Hussein, O. A.; Int. J. Chem. Process Eng. Res. 2014, 11, 109.

14. Al-Ghannam, S. M.; J. Food Drug Anal. 2008, 16, 19.

15. Hancu, G.; Kelemen, H.; Rusu, A.; Gyeresi, A.; J. Serb. Chem. Soc. 2013, 78, 1413.

16. Meyer, U. J.; Zhi, Z. L.; Loomans, E.; Spener, F.; Meusel, M.; Analyst 1999, 124, 1605.

17. Zhi, Z. L.; Meyer, U. J.; Van den Bedem, J. W.; Meusel, M.; Anal. Chim. Acta 2001, 442, 207.

18. Patel, S. A.; Patel, J. N.; Int. Res. J. Pharm. 2011, $2,123$.

19. Omar, M. A.; Abdelmageed, O. H.; Attla, T. Z.; Int. J. Anal. Chem. 2009, 1.

20. El-Shaboury, S. R.; Mohammed, F. A.; Saleh, G. A.; Rageh, A. H.; Nat. Sci. 2010, 2, 432.

21. Alwarthan, A. A.; Fattah, S. A.; Zahran, N. M.; Talanta 1992, 39, 703.

22. Saleh, G. A.; Askal, H. F.; Radwan, M. F.; Omar, M. A.; Talanta 2001, 54, 1205.

23. Rajendraprasad, N.; Basavaiah, K.; J. Anal. Chem. 2010, 65, 482.

24. Devi, O. Z.; Basavaiah, K.; Revanasiddappa, H. D.; Vinay, K. B.; J. Anal. Chem. 2011, 66, 490. 
25. Shah, J.; Jan, M. R.; Khan, M. N.; Inayatullah; J. Appl. Spectrosc. 2013, 79, 922.

26. Shaalan, R. A.; Cent. Eur. J. Chem. 2010, 8, 892.

27. Tabrizi, A. B.; J. Food Drug Anal. 2007, 15, 242.

28. Abdellatef, H. E.; El-Henawee, M. M.; El-Sayed, H. M.; Ayad, M. M.; Spectrochim. Acta, Part A 2006, 65, 996.

29. Mahgoub, H.; J. Pharm. Biomed. Anal. 2003, 31, 767.
30. Yu, F.; Chen, L.; Chen, F.; Microchim. Acta 2008, 161, 185.

31. Abdulghani, A. J.; Jasim, H. H.; Hassan, A. S.; Pak. J. Chem. 2012, 2, 1 .

Submitted: August 31, 2015 Published online: December 7, 2015 